\title{
Quantitative characteristic of Indonesian native chickens at the age of 4 months
}

\author{
Dika Irmaya, Depison *, Gushairiyanto \\ Animal Science Study Program, Faculty of Animal Science, University of Jambi, Jambi, 36361 \\ *Correspondence: depison.nasution@unja.ac.id
}

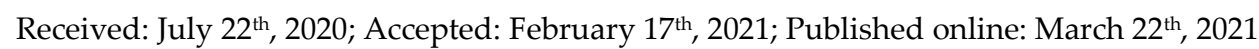

\section{Abstrak}

Tujuan: Ayam lokal (Kampung, Sentul dan Merawang) memiliki potensi besar untuk dikembangbiakkan baik sebagai penghasil daging maupun telur. Data kuantitatif ayam lokal belum banyak diketahui. Tujuan penelitian ini untuk mengetahui sifat kuantitatif ayam lokal (Kampung, Sentul dan Merawang) umur 1 bulan, 2 bulan, 3 bulan dan 4 bulan.

Metode: Materi penelitian ini adalah ayam lokal (Kampung, Sentul dan Merawang). Metode yang digunakan adalah eksperimen dengan jumlah sampel sebanyak 82 ekor pada setiap galur ayam dan jumlah total keseluruhan sebanyak 246 ekor. Data yang dihimpun adalah sifat kuantitatif. Sifat kuantitatif adalah sifat yang dipengaruhi oleh banyak pasangan gen, dapat diukur, dan dipengaruhi oleh faktor lingkungan. Data yang telah dikumpulkan dianalisis menggunakan uji beda rata-rata (uji-t). Vektor nilai rata-rata ukuran-ukuran tubuh galur ayam dianalisis menggunakan uji statistik T2-Hotelling. Uji statistik Analisis Komponen Utama untuk mengidentifikasi penciri bentuk dan ukuran tubuh pada masing-masing galur ayam. Pengolahan data dibantu dengan menggunakan perangkat lunak statistika Minitab versi 18.

Hasil: Hasil penelitian menunjukkan bahwa bobot badan, pertambahan bobot badan dan ukuran ukuran tubuh ayam Kampung pada umur 4 bulan berbeda nyata $(\mathrm{P}<0.05)$ lebih tinggi dibandingkan ayam Sentul dan ayam Merawang. Penciri ukuran ayam Kampung adalah lebar dada, sedangkan penciri bentuknya panjang punggung. Penciri ukuran ayam Sentul adalah panjang dada, sedangkan penciri bentuknya panjang tibia. Penciri ukuran ayam Merawang adalah panjang tibia, sedangkan penciri bentuknya panjang sayap.

Kesimpulan: Karakteristik kuantitatif (Bobot badan, pertambahan bobot badan dan ukuran ukuran tubuh) pada umur 4 bulan ayam Kampung lebih tinggi dibandingkan ayam Sentul dan ayam Merawang.

Kata Kunci: Ayam Kampung; Ayam Sentul; Ayam Merawang; Sifat Kuantitatif

\section{Abstract}

Objective: Native chickens (Kampung, Sentul, and Merawang) have great potential to be developed as both meat and egg producers. Quantitative data about native chickens are not widely known. The purpose of this research was to determine the quantitative characteristics of Native Chickens aged 1 month, 2 months, 3 months and 4 months.

Methods: The research material is native chickens. The method used was an 82 sample in each strain and a total of 246 samples. The data collected is of a quantitative traits. Quantitative traits are traits that are influenced by multiple gene pairs, can be measured, and are heavily influenced by 
environmental factors. Data collected were analyzed using the average difference test (t-test). The average value vector of body measurements of chicken lines was analyzed using the T2-Hotelling statistical test. Main Component Analysis statistical test to identify the shape and size characteristics of each chicken strain. Data processing was assisted by using Minitab statistical software version 18 . Results: The results of this study showed that body weight, weight gain and body size measurements of Kampung chicken were significantly different $(\mathrm{P}<0.05)$ higher than Sentul chicken and Merawang chickens. The identifier of the size of the Kampung chicken is the width of the chest, while the identifier of the shape is the length of the back. The identifier of Sentul chicken size is chest length, while the tibia is long. The characteristic of Merawang chicken is the length of the tibia, while the character of the shape is the wing length.

Conclusions: Quantitative characteristics (body weight, weight gain and body size measurements) at the age of 4 months Kampung chickens more heavily than Sentul chicken and Merawang chicken.

Keywords: Kampung Chicken; Sentul Chicken; Merawang Chicken; Quantitative Traits

\section{INTRODUCTION}

Chicken livestock is one of the animals that has made a major contribution to meeting the protein needs of animal origin for the people of Indonesia. Chicken meat needs have increased every year, due to increasing population, income, and public awareness about the importance of animal origin protein, and the price is relatively affordable by all groups of people [1]. One of the poultry that has the potential to be developed and spread evenly in all walks of life is native Chicken. Native chicken has several advantages including being more resistant to disease, can adapt to various environmental conditions, easy to maintain, tastes better and tastier and has a higher selling price [2].

Native chickens raised by the community consist of various lines, including Kampung, Sentul, and Merawang chickens. Kampung Chicken is a native chicken that is maintained by many Indonesian people but does not have special characteristics compared to other native chickens. Sentul Chicken is a native chicken from Ciamis Regency, West Java Province, and has been recognized as germplasm of Ciamis Regency based on Minister of Agriculture Decree No. 689 / Kpts.PD410 / 2/2013. Merawang chicken is a native chicken from Merawang Village, Merawang District, Bangka Regency, Bangka Belitung Islands Province, which has been recognized as germplasm through RI Minister of Agriculture Decree No. 2846 / Kpts / LB.4301812012 and is a genetic source and asset of the people of Bangka Belitung Province.

Kampung chicken, Sentul chicken, and Merawang chicken have great potential to be developed as both meat and egg producers. Seeing its potential as dual-purpose chickens, Kampung, Sentul and Merawang chickens are quite promising for breeding both on a small and commercial scale so that it can help fulfill animal protein and increase farmers' incomes. Genetic data about Kampung chicken, Sentul chicken, and Merawang chicken are not widely known. One effort that can be done to study this genetic characterization needs to be done.

Characterization plays a role in efforts to maintain, explore and develop the potential resources of each native chicken, the initial steps that need to be done include collecting information and characteristics related to several important economic traits such as body weight and body measurements [3]. Characterization can be identified by identifying the qualitative and quantitative traits of Kampung chickens, Sentul chickens and Merawang chickens.

Qualitative traits are characteristics that can be described in which individuals can be classified into one, two or more groups and the groupings differ markedly from one another. Qualitative traits are controlled by one or more genes and are little or not influenced by the environment.

Characterization can be identified by identifying quantitative traits of native chickens. Quantitative traits are measurable traits, influenced by many gene pairs and are 
strongly influenced by environmental factors. Environmental and genetic factors have a close relationship to express the genetic capacity of individuals, where ideal environmental conditions are needed [3].

Quantitative characteristics can be used to determine the level of livestock productivity, identification and identification of livestock including size and shape. Quantitative characteristics can be indicated by: length of the fermur, length of the tibia, length of the maxilla, length of the wing, length of the tarsometatarsus, circumference of the tarsometatarsus, height of the comb, length of the third finger (middle), length of the sternum, and body weight [4].

Until now, data regarding the quantitative traits of native chickens (Kampung, Sentul and Merawang) is not widely known, because not much research has been conducted. Therefore, an early selection program is needed in the context of a livestock breeding program for the development of germplasm in the future. Based on the description above, research has been carried out on "Characterization of quantitative traits of native chickens at the age of 4 months".

\section{MATERIALS AND METHODS}

\section{Materials}

This research is located in the Faculty of Animal Science University of Jambi which was carried out for 4 months starting from July to November 2019. This study used 82 chickens from each strain of Indonesian Native chickens (Kampung, Sentul and Merawang). Kampung chickens came from the jambi farm, Sentul chickens that came from PT. Sumber Unggas Indonesia, and Merawang chicken that came from BPTU Sembawa. SSS Furano WSP digital scales with a capacity of $3 \mathrm{~kg}$ with accuracy of $0.1 \mathrm{~g}$, stationery, and vaccine for the chicken. Vaccine for the chicken are presented in Table 1. Photo of the Indonesian Native Chickens (Kampung, Sentul and Merawang chickens) are presented in Figure 1, Figure 2 and Figure 3.

\section{Methods}

The method used in this study was an experiment on body weight, body weight gain and body measurements of native chickens. Chickens are kept from the age of DOC until the age of 4 months. The qualitative characteristics of the color of Kampung chicken feathers, both male and female, in the results of this study still vary widely. The results of this study the qualitative characteristics of Kampung chickens have a high degree of diversity [5]. Sentul chicken used in this study consists of 3 colors, namely gray, black and white. Sentul chickens are divided into 6 types, namely Sentul Batu (blackish ash), Sentul Abu (plain ash), Sentul Dust (ash like dust), Sentul Emas (yellowish ash), Sentul Geni (ash reddish) and Sentul Jambe (gray with red orange color) [6]. Merawang chicken used in the study was reddish brown in color, but there were also feather colors with a mixture of black and white. Qualitative characteristics of Merawang chickens include reddish brown feathers and yellow legs (calves) and a beak [7]. Chicken rearing system in a colony enclosure by providing commercial feed and drinking continuously (ad libitum). The composition of this feed is presented in Table 2 and feed intake is presented in Table 3. Each line is placed in a different cage with the other lines. The size of the cage was used is $4 \times 3 \mathrm{~m}$ for the capacity of 82 tails which is equipped with a place of feed, a place to drink and lighting lamps to match the age of the chicken. Weighing is done every month. Every weighed chicken is marked with a number sign on the wing.

\section{Observed Variables}

Data processing is assisted by using Minitab statistical software version 18. Data collected on morphometric characteristics include Body Weight, Head Length, Head Circumference, Head Height, Neck Length, Neck Circumference, Wings Length, Back Length, Back Height, Chest Length, Chest Width, Shank Length, Shank Circumference, Tibia Length, Tibia Circumference, Length of the Third Finger [8] [9]. Observed Variables of Indonesian Native Chicken are presented in Figure 4.

1. Body Weight (BW) is measured by weighing the chicken using a digital scale (gr). 
Table 1. Vaccine of Indonesian Native Chickens (Kampung, Sentul and Merawang)

\begin{tabular}{clll}
\hline Age (day) & Vaccine Type & \multicolumn{1}{c}{ Application } & \multicolumn{1}{c}{ Function } \\
\hline 4 & ND-IB & Eye Drops & Prevent ND \& IB disease \\
10 & Gumboro A & Drinking Water & Prevent gumboro disease \\
21 & ND La Sota & Drinking Water & Prevent ND disease \\
28 & Gumboro B & Drinking Water & Prevent gumboro disease \\
\hline
\end{tabular}

Table 2. Composition of Comfeed Broiler 1

\begin{tabular}{ccccc}
\hline Crude Protein (\%) & Crude Fat (\%) & Ca (\%) & Phosphor (\%) & ME (kkal) \\
\hline 21.00 & $3.0-7.0$ & $0.9-1.1$ & $0.6-0.9$ & 4100 \\
\hline
\end{tabular}

Source: PT. Japfa Comfeed (2013)

Table 3. Feed Intake of Indonesian Native Chickens

\begin{tabular}{cc}
\hline Age $($ Weeks $)$ & Feed Intake $(\mathrm{g} / \mathrm{b} / \mathrm{d})$ \\
\hline $0-1$ & 10 \\
$1-2$ & 15 \\
$2-3$ & 20 \\
$3-4$ & 30 \\
$4-5$ & 40 \\
$5-6$ & 50 \\
$6-7$ & 60 \\
$7-8$ & 75 \\
$8-16$ & 90 \\
\hline
\end{tabular}

2. Head length (HL) is measured from the base of the beak to the back of the head, using a digital calipers (mm).

3. Head circumference (HC) is measured at the highest part of the head by wrapping the measuring tape ( $\mathrm{cm}$ is converted to $\mathrm{mm})$.

4. Head Height $(\mathrm{HH})$ is measured at the highest part of the head using a digital calipers (mm).

5. Neck length (NL) is measured from the bones of the first cervical vetebrae to the last cervical vetebrae using a digital calipers (mm).

6. Neck circumference (NC) around the neck measuring tape ( $\mathrm{cm}$ converted to $\mathrm{mm}$ ).

7. Wings Length $(\mathrm{WL})$ is measured from the humerus bone to the tip of the phalanges using a measuring tape $(\mathrm{cm}$ converted to $\mathrm{mm})$.

8. Back length (BL) is measured from the base of the neck to the base of the tail using a measuring tape ( $\mathrm{cm}$ converted to $\mathrm{mm}$ ).

9. Back Height $(\mathrm{BH})$ is measured from the bottom of the chicken stand to the back using a ruler ( $\mathrm{cm}$ is converted to $\mathrm{mm}$ ).

10. Chest Length (CL) Chest length measurements (sternum) are carried out from the front end of the chest to the back end using the calipers ( $\mathrm{mm}$ ).

11. Chest Width (CW) Chest width measurements are obtained by measuring the distance from the left sternum to the right (the widest) using the digital calipers (mm).

12. Shank length (SL) is measured along the tarsometatarsus bone (shank) using a digital calipers (mm).

13. Shank Circumference (SC) encircles the measuring tape at the center of the tarsometatarsus bone (shank) $\quad(\mathrm{cm}$ converted to $\mathrm{mm}$ ).

14. Tibia Length (TL) is measured from the patella to the tip of the tibia measured using a digital calipers ( $\mathrm{mm}$ ).

15. Tibia circumference (TC) encircles the measuring tape on the tibia $(\mathrm{cm}$ is converted to $\mathrm{mm}$ ).

16. Length of the Third Finger (LTF) is measured from the base to the tip of the third finger measured using a digital calipers (mm).

\section{Data Analysis}

Data collected included body weight and body measurements grouped by sex, then 
corrected to male measurements. then analyzed using the average difference test (t-test). The mathematical model formula is as follows :

$$
\mathrm{t}=\frac{\bar{X}_{1}-\bar{X}_{2}}{\sqrt{\frac{\sum\left(X_{J 1}-\bar{X}_{1}\right)^{2}}{n_{1}\left(n_{1}-1\right)}+\frac{\sum\left(X_{J 2}-\bar{X}_{2}\right)^{2}}{n_{2}\left(n_{2}-1\right)}}}
$$

Note:

$\mathrm{t}=$ value of $\mathrm{t}$ count

$\bar{X}_{1}$ = sample mean in the first group,

$\bar{X}_{2}$ =sample mean in the second group,

$X_{j 1}=$ the value of the J-observation in the first group

$X_{j 2}=$ the value of the J-observation in the second group

$\mathrm{n} 1$ = number of samples in the first group, and

$\mathrm{n} 2$ = number of samples in the second group.

Decision Rule:

Accept $\mathrm{H} 0$ if $\mathrm{t}$-count $\leq \mathrm{t}$-table

Accept $\mathrm{H} 1$ if $\mathrm{t}$-count $>\mathrm{t}$-table

The average value vector of the two sex groups including: $\mathrm{HL}, \mathrm{HC}, \mathrm{HH}, \mathrm{NL}, \mathrm{NC}, \mathrm{WL}$, $\mathrm{BL}, \mathrm{BH}, \mathrm{CL}, \mathrm{CW}, \mathrm{SL}, \mathrm{SC}, \mathrm{TL}, \mathrm{TC}$, LTF were analyzed using the T2-Hotelling statistical test. The test is carried out by formulating the following hypothesis:

Ho: $\mathrm{U} 1=\mathrm{U} 2$ this means that the vector average value of the first herd together with the second herd.

$\mathrm{H} 1: \mathrm{U} 1 \neq \mathrm{U} 2$ meaning that the two vectors of mean value are different

T2-Hotelling is formulated as follows:

$$
T^{2}=\frac{n_{1} n_{2}}{n_{1}+n_{2}}\left(\overline{\overline{X_{1}}}-\overline{\overline{X_{2}}}\right) S_{G}^{-1}\left(\overline{\overline{X_{1}}}-\overline{\overline{X_{2}}}\right)
$$

next:

$$
F=\frac{n_{1}+n_{2}-p-1}{\left(n_{1}+n_{2}-2\right) p} T^{2}
$$

will have an $\mathrm{F}$ distribution with degrees of freedom $\mathrm{V} 1=\mathrm{p}$ and $\mathrm{V} 2=\mathrm{n} 1+\mathrm{n} 2-\mathrm{p}-1$

Note:

$\mathrm{T}^{2}=\mathrm{T}^{2}$-Hotelling statistical value

$\mathrm{F}=$ calculated value for T2-Hotelling $\mathrm{n}_{1}=$ number of observational data on the first livestock herd

$\mathrm{n}_{2}=$ amount of observation data in the second herd

$\bar{X}_{1}=$ vector mean value of random variables in the first herd

$\bar{X}_{2}=$ vector mean value of random variables in the second herd

$\mathrm{SG}^{-1}=$ inverse compound variance matrix (inverse of SG matrix)

$\mathrm{P} \quad=$ number of measuring variables

Two groups are declared equal if $\mathrm{T}^{2}$

$$
\mathrm{T}^{2} \leq \frac{\left(n_{1}+n_{2}-2\right) p}{n_{1}+n_{2}-p-1} F \alpha ; v_{1}, v_{2}
$$

Stated differently when $\mathrm{T}^{2}$

$$
\mathrm{T}^{2} \geq \frac{\left(n_{1}+n_{2}-2\right) p}{n_{1}+n_{2}-p-1} F \alpha ; v_{1}, v_{2} .
$$

Then a statistical test was performed to identify the determinants of body shape and size in Kampung, Sentul and Merawang chickens using Principal Component Analysis (PCA) [10]. The mathematical model used for this analysis is as follows:

Note:

$Y_{j} \quad=$ principal component $j(j=1,2 ; 1=$ size, 2 = shape )

$\mathrm{X}_{1,2,3 \ldots} \quad=$ variable $1,2,3 \ldots .7$

$\mathrm{a}_{\mathrm{ij}, 2,2,3, \ldots . .}=$ eigenvariable vector $\mathrm{i}(1,2,3, \ldots .7)$ and principal component $j$

$$
Y_{j}=a_{1 j} X_{1}+a_{2 j} X_{2}+a_{3 j} X_{3}+\ldots \ldots+a_{7 j} X
$$

\section{RESULT}

\section{Body Weight of Indonesian Native Chickens}

Body weight of Indonesian native chickens are presented in Table 3 the average body weight in sequence from highest to lowest is Kampung, Sentul and Merawang chickens. Based on the average difference test (t-test) that the body weight of native chickens was significantly different $(\mathrm{P}<0.05)$. The average weight of 1 month age show that the weight of Kampung chicken is not significantly different $(\mathrm{P}>0.05)$ with Sentul 

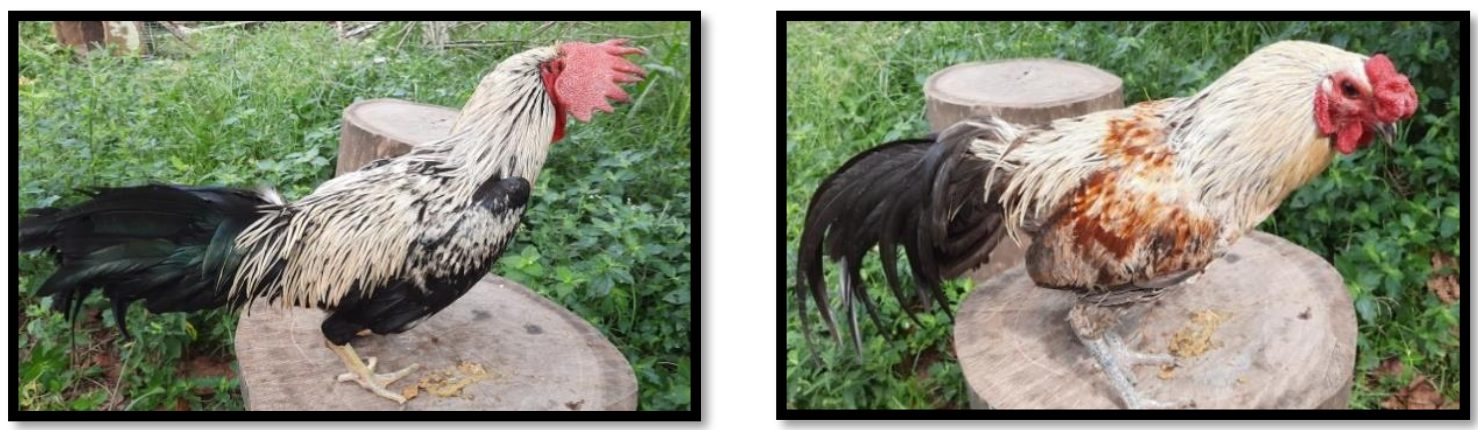

Figure 1. Kampung Chickens
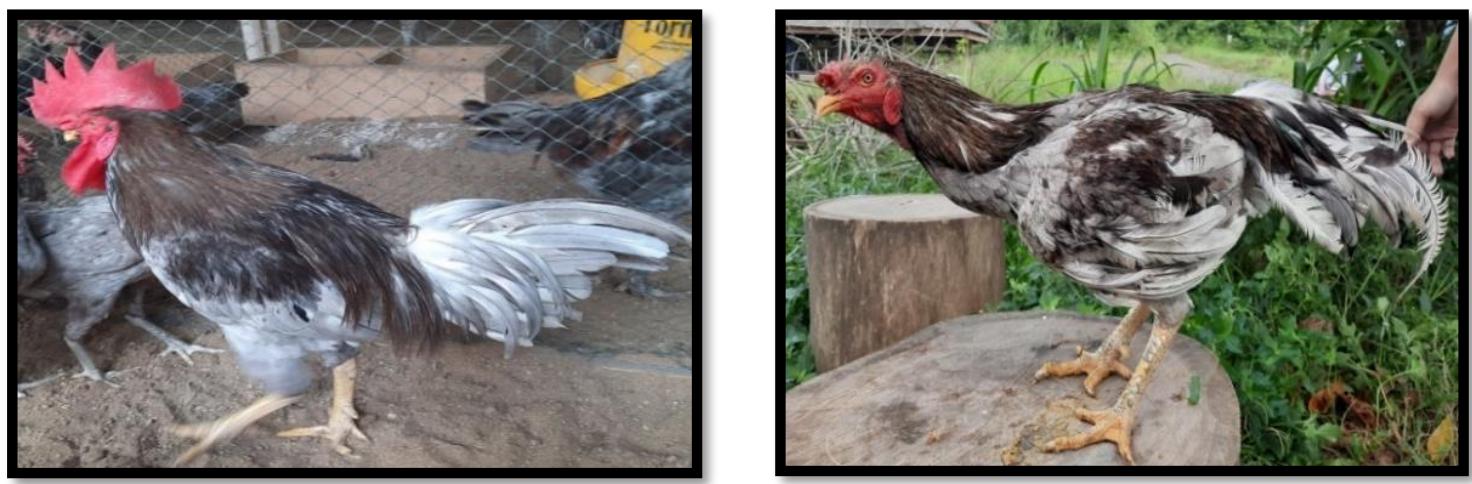

Figure 2. Sentul Chickens
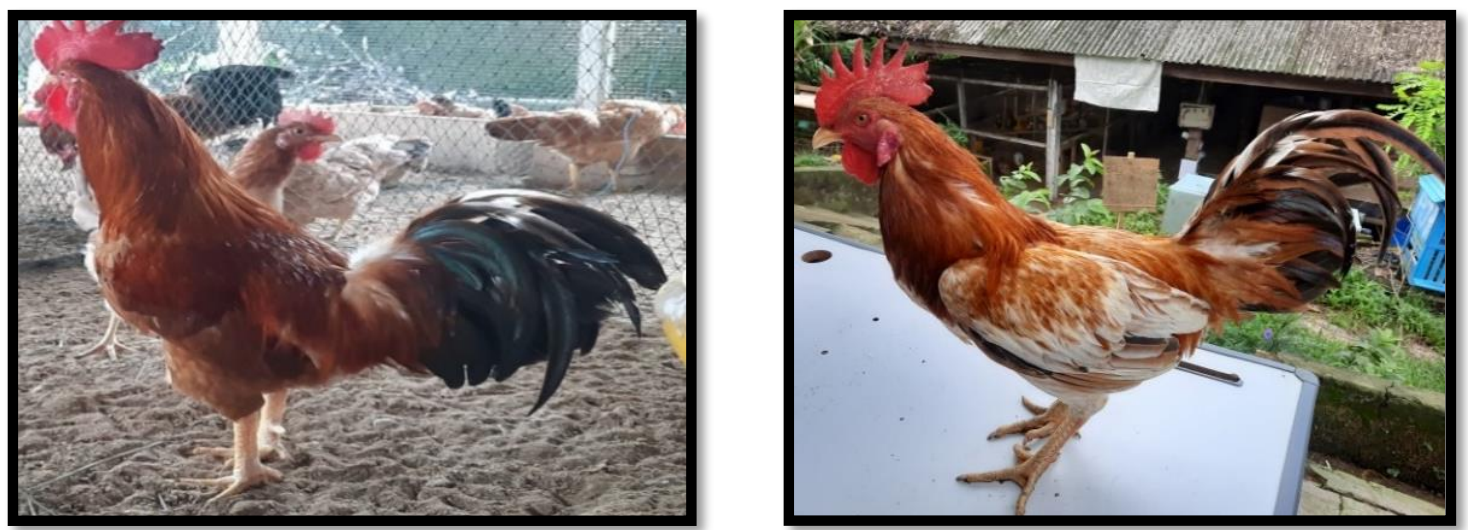

Figure 3. Merawang Chickens

chicken, but Kampung chicken and Sentul chicken are significantly different $(\mathrm{P}<0.05)$ with Merawang chicken. The average body weight of 2 months, 3 months and 4 months showed that the Kampung chicken was significantly different (P $<0.05)$ than Sentul chicken and Merawang chicken, while Sentul chicken was significantly different $(\mathrm{P}<0.05)$ compared to Merawang chicken. This shows that Kampung chicken has the heaviest compared to Sentul chicken and Merawang chicken.
Weight Gain of Indonesian Native Chickens

The weight gain of Kampung, Sentul and Merawang chickens DOC-4-month old are presented in Table 4 and Figure 4 the body weight gain of Kampung, Sentul and Merawang chickens from DOC-4 months old. The increase in body weight of Kampung chicken aged DOC-1 month, 1-2 months, 2-3 months and 3-4 months were $198.30 \pm 33.52 \mathrm{~g}$, $380.86 \pm 65.31 \mathrm{~g}, 372.87 \pm 76.31 \mathrm{~g}$, and $282.60 \pm$ $80.02 \mathrm{~g}$, at Sentul chicken were $184.31 \pm 37.79$ $\mathrm{g}, 414.72 \pm 46.70 \mathrm{~g}, 388.57 \pm 50.39 \mathrm{~g}$ and 165 $.92 \pm 92.94 \mathrm{~g}$, while in Merawang chicken they 


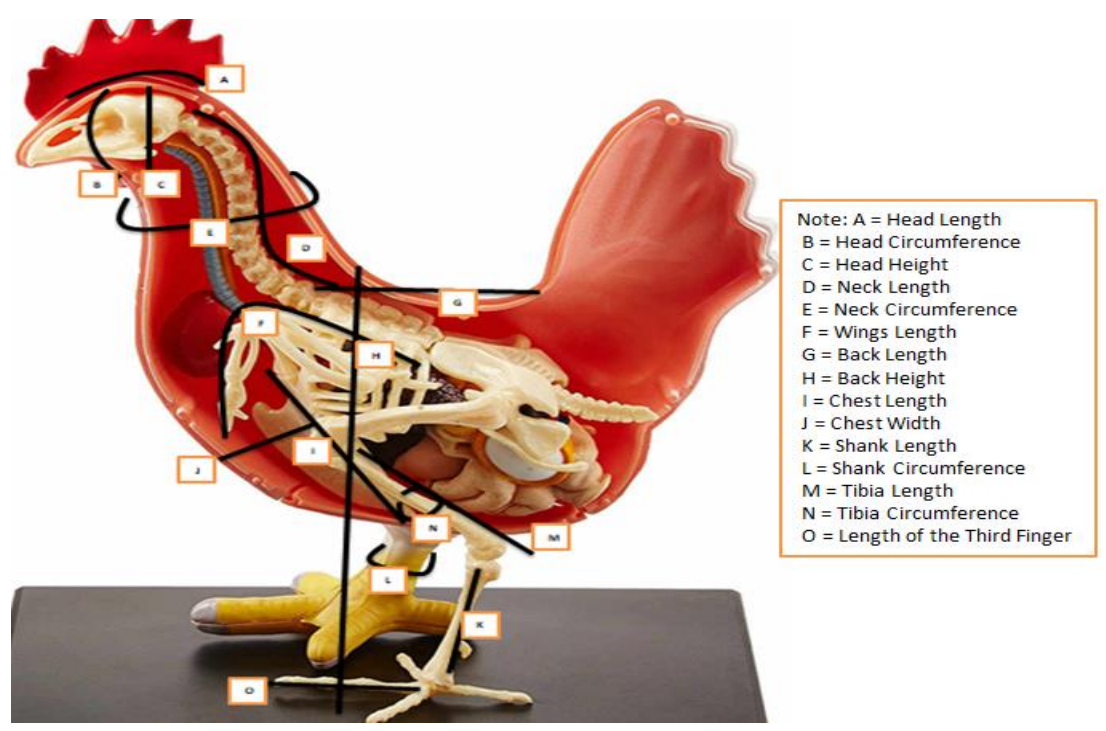

Figure 4. Observed Variables

were $173.90 \pm 41.41 \mathrm{~g}, 351.48 \pm 57.0 \mathrm{~g}, 301.75 \pm$ $112.07 \mathrm{~g}$ and $212.94 \pm 115.33 \mathrm{~g}$.

Based on the average difference test that the DOC-1 body weight gain in Kampung chicken was significantly different $(\mathrm{P}<0.05)$ with Sentul chicken and Merawang chicken, but the DOC-1 month weight gain in Sentul chicken was not significantly different $(P>0.05)$ with chickens dreamy. Body weight gain of 1-2 months of Kampung, Sentul and Merawang chickens were significantly different $(\mathrm{P}<0.05)$. Body weight gain of $2-3$ months of Kampung chicken was not significantly different $(\mathrm{P}>0.05)$ from Sentul chicken, but Kampung chicken was significantly different $(\mathrm{P}<0.05) \quad$ from Merawang chicken, whereas Sentul chicken's body weight gain was significantly different $(\mathrm{P}<0.05)$ from chicken Merawang. The 3-4 month weight gain of Kampung chicken was significantly different $(\mathrm{P}<0.05)$ with Merawang chicken and Sentul chicken, while the weight gain of Merawang chicken and Sentul chicken were not significantly different $(\mathrm{P}>0.05)$.

\section{Quantitative Characteristic of Indonesian Native Chickens at the Age of 4 Months}

Table 5 show information about the differences and similarities observed in the average body size of Kampung, Sentul and Merawang chickens obtained from the average difference test results. The results of this study indicate the highest average body size in a row are Kampung, Sentul and Merawang chickens. The results of the analysis of the difference in the average body measurements (HL, HC, HH, NL, NC, WL, BL,

Table 4. Body weight of Indonesian Native chickens

\begin{tabular}{lccc}
\hline \multirow{2}{*}{ Age } & \multicolumn{3}{c}{ Indonesian Native Chickens } \\
\cline { 2 - 4 } & Kampung Chickens & Sentul Chickens & Merawang Chickens \\
\hline DOC $(\mathrm{g})$ & $26.38 \pm 1.78^{\mathrm{a}}$ & $33.85 \pm 2.66^{\mathrm{b}}$ & $31.06 \pm 2.99^{\mathrm{c}}$ \\
1 Month (g) & $224.68 \pm 33.17^{\mathrm{a}}$ & $218.16 \pm 39.19^{\mathrm{a}}$ & $204.96 \pm 41.57^{\mathrm{b}}$ \\
2 Month $(\mathrm{g})$ & $605.53 \pm 60.98^{\mathrm{a}}$ & $632.88 \pm 71.20^{\mathrm{b}}$ & $556.45 \pm 59.37^{\mathrm{c}}$ \\
3 Month $(\mathrm{g})$ & $978.40 \pm 65.08^{\mathrm{a}}$ & $1021.44 \pm 78.09^{\mathrm{b}}$ & $858.20 \pm 113.83^{\mathrm{c}}$ \\
4 Month(g) & $1261.01 \pm 62.28^{\mathrm{a}}$ & $1187.36 \pm 85.95^{\mathrm{b}}$ & $1071.14 \pm 161.78^{\mathrm{c}}$ \\
\hline
\end{tabular}

Note: Different letter superscripts in the same column for each type of chicken mean significantly different (P $<0.05)$

Table 5. Weight Gain of Indonesian Native Chickens

\begin{tabular}{lcccc}
\multicolumn{1}{c}{ Type } & DOC-1 Month $(\mathrm{g})$ & 1-2 Months $(\mathrm{g})$ & 2-3 Months $(\mathrm{g})$ & 3-4 Months $(\mathrm{g})$ \\
\hline Kampung & 198.3 & 380.86 & 372.87 & 282.6 \\
Sentul & 184.31 & 414.72 & 388.57 & 165.92 \\
Merawang & 173.9 & 351.48 & 301.75 & 212.94 \\
\hline
\end{tabular}


$\mathrm{BH}, \mathrm{CL}, \mathrm{CW}, \mathrm{SL}, \mathrm{SC}, \mathrm{TL}, \mathrm{TC}, \mathrm{LTF}$ ) indicate that the body size of Kampung, Sentul and Merawang chickens were significantly different $(\mathrm{P}<0.05)$.

\section{T2-Hotteling Analysis of Body Measurements}

T2-Hotteling analysis aims to explain differences between herds. The results of this study indicate T2-Hotteling analysis of body measurements including $\mathrm{HL}$, $\mathrm{HC}, \mathrm{HH}, \mathrm{NL}, \mathrm{NC}, \mathrm{WL}, \mathrm{BL}, \mathrm{BH}, \mathrm{CL}, \mathrm{CW}$, SL, SC, TL, TC, LTF Kampung, Sentul and Merawang chickens served in Table 6. The results of T2-Hotteling analysis of quantitative characteristics showed that the body measurements of Kampung chicken were significantly different $(\mathrm{P}<0.01)$ compared to Sentul and Merawang chicken, Sentul chicken body sizes were significantly different $(\mathrm{P}<0.01)$ compared to Merawang chicken.

\section{Principal Component Analysis}

The size equation, shape equation, total diversity, and eigenvalues of Kampung, sentul and Merawang chickens are presented in Table 7. The determinants of the size and shape of these Indonesian Native Chickens were obtained using Principal Component Analysis (PCA). Main Component Analysis aims to explain the structure of variancecovariance (a combination of diverse multivariate data) through a linear combination of certain variables, while in general, it aims to reduce the data and interpret it [5]. The total diversity of the 1st main component which is equivalent to body size in Kampung chickens is $92.3 \%$, in Sentul chickens it is $83.3 \%$, while in Merawang chickens it is $85.8 \%$. The total diversity of the second main component, which is equivalent to the body shape of the Kampung chicken is $2.1 \%$, in Sentul chicken is $5.8 \%$, while in Merawang chicken it is $3.7 \%$. This percentage

Table 6. Average body measurements of Indonesian Native chickens at the age of 4 months

\begin{tabular}{lccc}
\hline Body Measurements & Kampung Chickens & Sentul Chickens & Merawang Chickens \\
\hline HL $(\mathrm{mm})$ & $47.81 \pm 1.77^{\mathrm{a}}$ & $41.11 \pm 0.99^{\mathrm{b}}$ & $39.82 \pm 2.03^{\mathrm{c}}$ \\
HH $(\mathrm{mm})$ & $35.71 \pm 1.44^{\mathrm{a}}$ & $34.95 \pm 1.22^{\mathrm{b}}$ & $33.96 \pm 2.16^{\mathrm{c}}$ \\
HC $(\mathrm{mm})$ & $126.98 \pm 5.23^{\mathrm{a}}$ & $112.91 \pm 4.93^{\mathrm{b}}$ & $116.51 \pm 5.49^{\mathrm{c}}$ \\
NL $(\mathrm{mm})$ & $155.46 \pm 5.87^{\mathrm{a}}$ & $140.54 \pm 5.23^{\mathrm{b}}$ & $137.98 \pm 9.49^{\mathrm{c}}$ \\
CN $(\mathrm{mm})$ & $107.22 \pm 6.35^{\mathrm{a}}$ & $95.10 \pm 5.43^{\mathrm{b}}$ & $92.22 \pm 7.65^{\mathrm{c}}$ \\
WL $(\mathrm{mm})$ & $230.93 \pm 6.91^{\mathrm{a}}$ & $195.45 \pm 7.86^{\mathrm{b}}$ & $188.12 \pm 11.81^{\mathrm{c}}$ \\
BL $(\mathrm{mm})$ & $229.90 \pm 5.82^{\mathrm{a}}$ & $212.76 \pm 6.97^{\mathrm{b}}$ & $207.43 \pm 16.23^{\mathrm{c}}$ \\
BH $(\mathrm{mm})$ & $301.95 \pm 8.22^{\mathrm{a}}$ & $293.17 \pm 11.17^{\mathrm{b}}$ & $287.61 \pm 15.87^{\mathrm{c}}$ \\
CL $(\mathrm{mm})$ & $144.88 \pm 6.92^{\mathrm{a}}$ & $126.78 \pm 5.39^{\mathrm{b}}$ & $121.54 \pm 8.84^{\mathrm{c}}$ \\
CW $(\mathrm{mm})$ & $75.99 \pm 5.35^{\mathrm{a}}$ & $61.41 \pm 3.16^{\mathrm{b}}$ & $57.77 \pm 5.24^{\mathrm{c}}$ \\
SL $(\mathrm{mm})$ & $94.46 \pm 5.78^{\mathrm{a}}$ & $83.54 \pm 6.11^{\mathrm{b}}$ & $79.62 \pm 8.23^{\mathrm{c}}$ \\
SC $(\mathrm{mm})$ & $50.83 \pm 3.80^{\mathrm{a}}$ & $48.56 \pm 2.68^{\mathrm{b}}$ & $46.71 \pm 4.39^{\mathrm{c}}$ \\
TL $(\mathrm{mm})$ & $149.74 \pm 5.91^{\mathrm{a}}$ & $126.49 \pm 5.39^{\mathrm{b}}$ & $119.81 \pm 8.38^{\mathrm{c}}$ \\
TC $(\mathrm{mm})$ & $120.27 \pm 6.06^{\mathrm{a}}$ & $107.80 \pm 8.28^{\mathrm{b}}$ & $103.87 \pm 9.95^{\mathrm{c}}$ \\
LTF $(\mathrm{mm})$ & $77.01 \pm 5.40^{\mathrm{a}}$ & $66.50 \pm 5.77^{\mathrm{b}}$ & $64.29 \pm 5.79^{\mathrm{c}}$
\end{tabular}

Note: Different letter superscripts in the same line for each type of chicken mean significantly different $(\mathrm{P}$ $<0.05), \mathrm{HL}=$ Head Length, $\mathrm{HH}=$ Head Height, $\mathrm{HC}=$ Head Circumference, $\mathrm{NL}=$ Neck Length, $\mathrm{CN}=$ Circumference Neck, $\mathrm{WL}=$ Wings Length, $\mathrm{BL}=$ Back Length, $\mathrm{BH}=$ Back Height, $\mathrm{CL}=$ Chest Length, $\mathrm{CW}$ $=$ Chest Width, $\mathrm{SL}=$ Shank Length, $\mathrm{SC}=$ Shank Circumference, $\mathrm{TL}=$ Tibia Length, $\mathrm{TC}=$ Tibia Circle, $\mathrm{LTF}$ $=$ Length Third Finger.

Table 7. T2-Hotteling Analysis of body measurements of Native Chickens

\begin{tabular}{lcccc}
\hline \multicolumn{1}{c}{ Body Measurements } & Statistics T2 Hotteling & F Value & P Value & Conclusion \\
\hline K-S & 2152.563583 & 121.978603 & 0.00 & $* *$ \\
K-M & 6808.067647 & 385.7905 & 0.00 & $* *$ \\
S-M & 267.0412158 & 15.13233556 & 0.00 & $* *$ \\
\hline
\end{tabular}

Note: $\mathrm{K}=$ Kampung, $\mathrm{S}=$ Sentul, $\mathrm{M}=$ Merawang, ${ }^{* *}=$ Significantly Different $(\mathrm{P}<0.01)$ 
represents the largest proportion of diversity among the main components obtained.

\section{DISCUSSION}

\section{Body Weight of Indonesian Native Chickens}

Productivity such as growth is a quantitative trait which is a combination of genetic factors and environmental factors. Research on growth is very important, namely by measuring body weight at a certain age or during growth [6]. The average body weight of 4 months old in Kampung chicken is $1261.01 \pm 62.28 \mathrm{~g}$, Sentul chicken is $1187.36 \pm$ $85.95 \mathrm{~g}$ and Merawang chicken is $1071.14 \pm$ 161.78 g. Differences in average body weight of Kampung, Sentul and Merawang chickens occur due to increased growth of different chickens, this is likely due to the influence of genetic factors of each chicken. There was a difference in the increase in chicken growth due to genetic factors [7]. Genetic factors can affect differences in body weight, even though given the same feed ad libitum [8]. The best growth among the three chickens is Kampung chicken.

As the chicken ages, body weight also increases. The highest peak of growth of Kampung, Sentul and Merawang chickens is at the age of 2 months. This indicates that the maximum growth occurs until before the age of 2 months. Growth will still occur in the following week, but there is a decrease in the speed of growth both in Kampung, Sentul and Merawang chickens. The age of 12 to 20 weeks there will be a decrease in the rate of growth until reaching adulthood [9]. The weight gain of Sentul chickens continue to increase or grow rapidly at the age of $1-2$ months and decrease after the age of 2 months [10].

\section{Weight Gain of Indonesian Native Chickens}

The increase in body weight of Kampung, Sentul and Merawang chickens has a sigmoid shape, meaning that after growth reaches an inflection point then slowing growth occurs. That growth curves generally form curves with a sigmoid shape. A growth curve is a reflection of an animal's ability to display genetic potential and the development of body parts to adulthood [11]. The growth rate starts to slow down after the age of 2 months, thus the maintenance of Kampung, Sentul and Merawang chickens for the purpose of meat production can be done in a shorter time.

\section{Quantitative characteristic of Indonesian Native Chickens at the Age of 4 Months}

Quantitative characteristics of Kampung chicken in this research have a higher body size than Sentul chicken and Merawang chicken. The characteristics of native chickens if kept intensively will have a higher body size than traditional maintenance [12]. The difference in performance between Kampung, Sentul and Merawang chickens is thought to be due to genetic influences, while the environmental effect is very small because there are no differences in maintenance management during this research. The difference in body size parameters is thought to be caused by genetic diversity [10].

Weight Gain

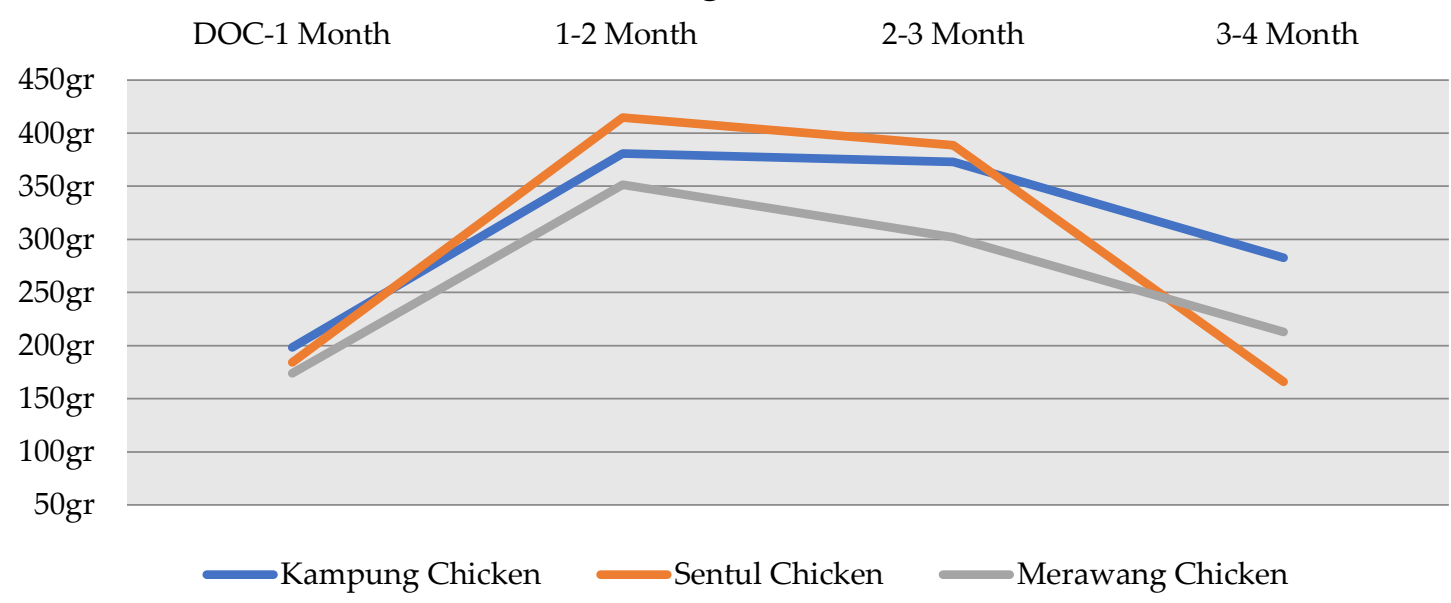

Figure 5. Graph of Indonesian Native Chickens body weight gain up to 4 months 
Table 8. Quantitative characteristics of Native chickens at 4 months

\begin{tabular}{|c|c|c|c|c|c|}
\hline Type & & & Equation & TD (\%) & $\Lambda$ \\
\hline \multirow{2}{*}{$\begin{array}{l}\text { Kampung } \\
\text { Chickens }\end{array}$} & $\begin{array}{l}\text { Body } \\
\text { Size }\end{array}$ & $=$ & $\begin{array}{l}0.259 \mathrm{HL}+0.261 \mathrm{HH}+0.26 \mathrm{HC}+0.26 \mathrm{NL}+0.265 \mathrm{CN}+ \\
0.262 \mathrm{WL}+0.258 \mathrm{BL}+0.261 \mathrm{BH}+0.26 \mathrm{CL}+0.266 \mathrm{CW}+ \\
0.25 \mathrm{SL}+0.26 \mathrm{SC}+0.231 \mathrm{TL}+0.258 \mathrm{TC}+0.26 \mathrm{LTF}\end{array}$ & 92.3 & 13.85 \\
\hline & $\begin{array}{l}\text { Body } \\
\text { Shape }\end{array}$ & $=$ & $\begin{array}{l}.097 \mathrm{HL}-0.096 \mathrm{HH}+0.081 \mathrm{HC}-0.199 \mathrm{NL}-0.158 \mathrm{CN} \\
-0.168 \mathrm{WL}+0.883 \mathrm{BL}+0.095 \mathrm{BH}-0.011 \mathrm{CL}-0.151 \mathrm{CW} \\
+0.096 \mathrm{SL}+0.029 \mathrm{SC}+0.136 \mathrm{TL}-0.0194 \mathrm{TC}-0.063 \mathrm{LTF}\end{array}$ & 2.1 & 0.32 \\
\hline \multirow{2}{*}{$\begin{array}{l}\text { Sentul } \\
\text { Chickens }\end{array}$} & $\begin{array}{l}\text { Body } \\
\text { Size }\end{array}$ & $=$ & $\begin{array}{l}0.273 \mathrm{HL}+0.264 \mathrm{HH}+0.119 \mathrm{HC}+0.272 \mathrm{NL}+0.275 \mathrm{CN} \\
+0.258 \mathrm{WL}+0.27 \mathrm{BL}+0.265 \mathrm{BH}+0.276 \mathrm{CL}+0.263 \mathrm{CW} \\
+0.269 \mathrm{SL}+0.266 \mathrm{SC}+0.262 \mathrm{TL}+0.241 \mathrm{TC}+0.258 \mathrm{LTF}\end{array}$ & 83.3 & 12.50 \\
\hline & $\begin{array}{l}\text { Body } \\
\text { Shape }\end{array}$ & $=$ & $\begin{array}{l}0.077 \mathrm{HL}+0.081 \mathrm{HH}-0.961 \mathrm{HC}+0.053 \mathrm{NL}+0.003 \mathrm{CN} \\
-0.042 \mathrm{WL}+0.017 \mathrm{BL}-0.009 \mathrm{BH}+0.115 \mathrm{CL}-0.024 \mathrm{CW} \\
-0.096 \mathrm{SL}-0.001 \mathrm{SC}+0.148 \mathrm{TL}+0.115 \mathrm{TC}+0.002 \mathrm{LTF}\end{array}$ & 5.8 & 0.88 \\
\hline \multirow{2}{*}{$\begin{array}{l}\text { Merawang } \\
\text { Chickens }\end{array}$} & $\begin{array}{l}\text { Body } \\
\text { Size }\end{array}$ & & $\begin{array}{l}0.253 \mathrm{HL}+0.266 \mathrm{HH}+0.271 \mathrm{HC}+0.269 \mathrm{NL}+0.246 \mathrm{CN} \\
+0.243 \mathrm{WL}+0.224 \mathrm{BL}+0.258 \mathrm{BH}+0.267 \mathrm{CL}+0.235 \mathrm{CW} \\
+0.26 \mathrm{SL}+0.272 \mathrm{SC}+0.274 \mathrm{TL}+0.261 \mathrm{TC}+0.27 \mathrm{LTF}\end{array}$ & 85.8 & 12.87 \\
\hline & $\begin{array}{l}\text { Body } \\
\text { Shapes }\end{array}$ & & $\begin{array}{l}0.11 \mathrm{HL}-0.182 \mathrm{HH}-0.117 \mathrm{HC}-0.029 \mathrm{NL}+0.333 \mathrm{CN}+ \\
0.430 \mathrm{WL}-0.687 \mathrm{BL}-0.261 \mathrm{BH}+0.067 \mathrm{CL}-0.086 \mathrm{CW}+ \\
0.217 \mathrm{SL}+0.145 \mathrm{SC}-0.115 \mathrm{TL}-0.097 \mathrm{TC}+0.117 \mathrm{LTF}\end{array}$ & 3.7 & 0.55 \\
\hline
\end{tabular}

Note: $\mathrm{HL}=$ Head Length, $\mathrm{HH}=$ Head Height, $\mathrm{HC}=$ Head Circumference, NL = Neck Length, $\mathrm{CN}=$ Circumference Neck, WL = Wings Length, $\mathrm{BL}=$ Back Length, $\mathrm{BH}=$ Back Height, $\mathrm{CL}=$ Chest Length, $\mathrm{CW}$ $=$ Chest Width, SL = Shank Length, SC = Shank Circumference, $\mathrm{TL}=$ Tibia Length, $\mathrm{TC}=$ Tibia Circle, $\mathrm{LTF}$ =Length Third Finger, TD = Total Diversity

Differences in quantitative traits are caused by genetics and the environment, high diversity of phenotypic traits due to genetic interactions, while the influence of the environment is very small [13]. Livestock body size may differ from each other due to the possibility of differences in genetic diversity, location of origin and mating systems applied in the area [14].

\section{T2-Hotteling Analysis of Body Measurements}

Based on the T2 hotelling analysis, it can be stated that Kampung chicken have larger body measurements than Sentul and Merawang chickens, while Sentul chicken body sizes are larger than Merawang chicken, this shows that Merawang chicken have the most body measurements small compared to the others. Merawang chicken has several advantages including a greater body size when compared to other native chickens [15]. The difference in body sizes is thought to be due to genetic differences between the three chicken strains. Body parts are growth parameters, where body size is an inherited trait/genetic [16]. Diversity in livestock can be sourced from genetic diversity, where genetic diversity can be caused by additive genes, dominant genes and epistasis genes [17].

\section{Principal Component Analysis}

The size equation, shape equation, total diversity, and eigenvalues of Kampung, Sentul and Merawang chickens are presented in Table 4. The determinants of the size and shape of these Kampung chicken were obtained using Principal Component Analysis (PCA). Main Component Analysis aims to explain the structure of variance-covariance (a combination of diverse multivariate data) through a linear combination of certain variables, while in general, it aims to reduce the data and interpret it [5]. Principal component analysis is used to determine parameters indicating the determinants of the nation and is called the differentiator of the nation [18].

Table 8 shows that the equation of body size score for Kampung, Sentul and Merawang chickens respectively were $92.3 \%$, $83.3 \%$ and $85.8 \%$. This percentage is the largest proportion of diversity among the main components obtained. The results of the 
analysis of the main components are numbers on PC1 and PC2, PC1 can be interpreted as a "size" vector and PC2 can be interpreted as a "shape" vector [19]. The highest eigenvector in the Kampung chicken body size equation is chest width (CW). This means that $\mathrm{CW}$ can be used as a marker of size in Kampung chicken because it has the largest contribution to the size equation. The characteristic size of the results of the analysis of the main components of Kampung chicken is the wing length (WL) [20]. The highest eigenvector in the Kampung chicken body size equation is chest width $(\mathrm{CW})$ and the highest eigenvectors obtained in the body shape equation of Kampung chicken is back length (BL) [21]. The highest eigenvector obtained in the Sentul body size equation is breast length (BL). This means that BL is a measure of size because it has the largest contribution to the size equation, breast length (BL) can be used as an estimator of Sentul chicken body weight. The highest eigenvector obtained in the Merawang chicken body size equation is tibia length (TL). This means that TL is a size identifier because it has the largest contribution to the size equation, tibia length (TL) can be used as an estimator of Merawang chicken body weight. The highest eigenvectors obtained in the body shape equation of Kampung, Sentul and Merawang chickens were respectively the back length (BL), tibia length (TL), and wing length (WL). The equation of body size and body shape native chickens in the results of this research are differences. Differences in body size and body shape in livestock can be caused by differences in genetic factors [22].

\section{CONCLUSION}

Quantitative characteristics (body
weight, weight gain and body size
measurements) at the age of 4 months
Kampung chicken are better than Sentul
chicken and Merawang chicken. The identifier
of the size of the Kampung chicken is chest
width, while the identifier of the shape is
back length. The identifier of Sentul chicken
size is chest length, while the character of
the shape is tibia length. The characteristic
of Merawang chicken is the tibia length, while
the character of the shape is wing length.

\section{CONFLICT OF INTEREST}

The author declares that he has no conflict of interests.

\section{ACKNOWLEDGMENTS}

Thank you for the Animal Science Study Program, Faculty of Animal Science, University of Jambi.

\section{REFERENCES}

1. Umam, M.K., H. S. Prayogi, and V. M. A. Nurgiartiningsih. 2014. The performance of Broiler rearing in system stage floor and double floor. J. Ilm-ilm. Pet. 24:79-87. https://jiip.ub.ac.id/index.php/jiip/article/v iew $/ 207$

2. Nuraini., Z. Hidayat, and K. Yolanda. 2018. Performa bobot badan akhir, bobot karkas serta persentase karkas ayam Merawang pada keturunan dan jenis kelamin yang berbeda. Si. Pet. 16:69-73. https://jurnal. uns.ac.id/Sains-Peternakan/article/view/23 236

3. Sitanggang, E.N., Hasnudi and, Hamdan, 2016. Keragaman sifat kualitatif dan morfometrik antara ayam Kampung, ayam Bangkok, ayam Katai, ayam Birma, ayam Bagon dan Magon di Medan. J. Pet. Intr. 3:167-189. https://talenta.usu.ac.id/jpi/ article/view/2753/2099

4. Ashifudin, M., E. Kurnianto, and Sutopo. 2017. Karakteristik morfometrik ayam Kedu jengger merah dan jengger hitam generasi pertama di satker ayam MaronTemanggung. J. Ilm. Tern. 17:40-46. http://jurnal.unpad.ac.id/jurnalilmuternak /article/view/14825

5. Gasperz, V. 2006. Teknik analisis dalam penelitian percobaan. Tarsito, Bandung.

6. Awaludin. 2012. Strategi pengembangan ayam Biromaru dalam upaya penyediaan bibit ayam pedaging lokal. Ijas 2: 64-70. doi: https://doi.org/10.24198/ijas.v2i2.2735. g2371.

7. Pagala, M.A., L. A. Nafiu, and S. Maharani. 2019. Keragaan ukuran dimensi tubuh hasil persilangan ayam Petelur dan Bangkok pada fase starter. J. Ilm. Tek. Pet. Trop. 6:251-258. doi: http://dx.doi.org/ 
10.33772/jitro.v6i2.7140.

8. Djego, Y., J. N. Kihe, and H. T. Pangestuti. 2019. Efek komposisi genotip dari ayam ras Petelur, Kate dan lokal Sabu terhadap sifatsifat pada bobot badan dan ukuran tubuh. J. Nuk. Pet. 6:20-25. doi: https://ejurnal. undana.ac.id/nukleus/article/view/1890.

9. Trisiwi, H. F. 2017. Pengaruh level protein pakan pada masa pertumbuhan terhadap penampilan pada awal peneluran ayam betina hasil persilangan ayam Kampung jantan dan ayam ras Petelur betina. J. Ilm. Tek. Has. Tern. 12:61-68. doi:https://doi. org/10.21776/ub.jitek.2017.012.02.1.

10. Urfa, S., H. Indijani, and W. Tanwiriah. 2017. Model kurva pertumbuhan ayam Kampung Unggul Balitnak (KUB) umur 012 minggu. J. Ilm. Tern. 17:59-66. doi:// https://doi.org/10.24198.jit.v17i1.14863.

11. Rajab., B. J. Papilaya. 2012. Sifat kuantitatif ayam Kampung lokal pada pemeliharaan tradisional. Agrinim. 2:61-64. https:// ejournal.unpatti.ac.id/ppr_paperinfo_lnk. php?id=320

12. Puteri, N. I., Gushairiyanto, and Depison. 2020. Growth patterns, body weight and morphometric of KUB chicken, Sentul chicken and Arab Chicken. Bul. Pet. 44:67-72. https://doi.org/10.21059/buletin peternak.v44i3.57016

13. Alwi, M., C. Sumantri, and S. Darwati. 2014. Karakteristik genetik dan fenotip ayam Nunukan di Pulau Tarakan, Kalimantan Timur. J. Vet. 15:173-181. https://ojs.unud.ac.id/index.php/jvet/articl e/view/9644

14. Hikmawaty,. A. Gunawan., RR. Noor, and Jakaria. 2014. Identifikasi ukuran tubuh dan bentuk tubuh sapi Bali di beberapa pusat pembibitan melalui pendekatan analisis komponen utama. J. Ilm. Prod. Tek. Has. Pet. 2: 231-237. doi: https://journal. ipb.ac.id/index.php/ipthp/article/view/155 71

15. Magfira., R. I. Arifiantini., N. W. K. Karja, andS. Darwati. 2017. Efektivitas low density lipoprotein dan kuning telur ayam dan puyuh pada pengawetan semen ayam Merawang (effectivess of low density lipoprotein and egg yolk from chicken and quail on Merawang semen preservation). J.
Vet. 18:345-352. https://doi.org/10.19087/ jveteriner.2017.18.3.345.

16. Pamungkas, F. A., 2005. Beberapa kriteria analisis penduga bobot tetas dan bobot hidup umur 12 minggu dalam seleksi ayam Kampung. JITV. 10:281-285. https:// core.ac.uk/download/pdf/236129371.pdf

17. Lukmanudin, M., C. Sumantri, and S. Darwati. 2018. Ukuran tubuh ayam lokal silangan ipb d-1 generasi kelima umur 2 sampai 12 minggu. J. Ilm. Prod. Tek. Has. Pet. 6: 113-120. https://doi.org/10.29244/ jipthp.6.3.113-120.

18. Mariandayani, H. N., D. D. Solihin., S. Sulandari., and C. Sumantri. 2013. Keragaman fenotipik dan pendugaan jarak genetik pada ayam lokal dan ayam broiler menggunakan analisis morfologi (phenotypic variation and estimation genetic distance between local chicken and broiler chicken using morphological analysis). J. Vet. 14:475-484. https://ojs. unud.ac.id/index.php/jvet/article/view/768 3

19. Kurnianto, E., S. Sutopo., E. Purbowati., E.T. Setiatin., D. Samsudewa, and T. Permatasari. 2013. Multivariate analysis of morfphological traits of local goats in Central Java-Indonesia. Iran. J. App. Anim. Sci. 3:361- 367. http://ijas.iaurasht.ac.ir/ article_513999.html

20. Permadi, A.N.N., E. Kurnianto, and Sutiyono. 2020. Karakteristik morfometrik ayam Kampung jantan dan betina di Desa Tirtomulyo Kecamatan Plantungan, Kabupaten Kendal, Jawa Tengah. J. Pet. Ind. 22:11-20. https://doi.org/10.25077/jpi. 22.1.11-20.2020

21. Putri, A. B. S. R. N., Gushairiyanto, and Depison. 2020. Bobot badan dan karakteristik morfometrik beberapa galur ayam lokal. Jurnal Ilmu dan Teknologi Peternakan Tropis. 7(3): 256-263. DOI: http://dx.doi.org/10.33772/jitro.v7i3.12150.

22. Mahmudi., R. Priyanto, and Jakaria. 2019. Karakteristik morfometrik sapi Aceh, sapi PO dan sapi Bali berdasarkan analisis komponen utama (aku). J. Ilm. Prod. Tek. Has. Pet. 7:35-40. https://journal.ipb.ac.id/ index.php/ipthp/article/view/25040. 